\title{
Triiodothyronine Uptake Measurement
}

National Cancer Institute

\section{Source}

National Cancer Institute. Triiodothyronine Uptake Measurement. NCI Thesaurus. Code C74748.

The determination of the binding of triiodothyonine to thyroxine binding globulin protein in a sample. 